\title{
Reinvestigation of vitellogenesis in Caryophyllaeus laticeps (Pallas, 1781) (Cestoda, Caryophyllidea, Caryophyllaeidae), monozoic tapeworm of Abramis brama (Pisces, Teleostei)
}

\author{
M. BRUŇANSKÁ ${ }^{1}$, P. DROBNÍKOVÁ2 ${ }^{2}$ J. S. MACKIEWICZ ${ }^{3}$, J. NEBESÁŘOVÁ ${ }^{4}$
}

\begin{abstract}
${ }^{1}$ Institute of Parasitology, Slovak Academy of Sciences, Hlinkova 3, 04001 Košice, Slovak Republic, E-mail: brunan@saske.sk $;{ }^{2}$ Faculty of Biological Sciences, University of South Bohemia, 37005 České Budějovice, Czech Republic; ${ }^{3}$ Department of Biological Sciences, University at Albany, State University of New York, Albany, New York, 12222, USA; ${ }^{4}$ Institute of Parasitology, Biology Centre of the Academy of Sciences of the Czech Republic, Branišovská 31, 37005 České Budějovice, Czech Republic
\end{abstract}

\section{Summary}

Reinvestigation of vitellogenesis in the caryophyllidean cestode Caryophyllaeus laticeps (Pallas, 1781) has been performed using light microscope (LM) and transmission electron microscopy (TEM), and cytochemical staining with periodic acid-thiosemicarbazide-silver proteinate (PA-TSC-SP) for glycogen. Vitellogenesis is generally similar to that reported in the past, however, some new observations were made. The present study reveals the first evidence of: (i) interstitial tissue in the vitelline follicles, (ii) lipid droplets in maturing and mature vitellocytes from vitelline follicles, and (iii) lamellar bodies in vitellocytes from the vitelloduct in $C$. laticeps. Projections of interstitial tissue surround each vitellocyte and the follicle periphery. The perinuclear cytoplasm of the interstitial tissue contains granular endoplasmic reticulum and vesicles of various size and density. Cytoplasmic osmiophobic lipid droplets and lamellar bodies, previously believed to be absent in most caryophyllid cestodes, are readily apparent in vitellocytes of $C$. laticeps. The origin and presumed function of these inclusions are discussed. On the other hand, the formation and storage of massive amounts of glycogen in the nucleus and large amounts in the cytoplasm of mature vitelline cells are similar to the condition found in other caryophyllids. Results are compared and contrasted with previous studies on vitellogenesis in other monopleuroid cestodes (Amphilinidea and Gyrocotylidea) as well as polypleuroid cestodes (Spathebothriidea ) and the remaining strobilated Eucestoda.

Keywords: Caryophyllidea; Caryophyllaeus laticeps; vitellogenesis; vitellocyte; ultrastructure

\section{Introduction}

Ultrastructural characters of the vitellarium might be useful for a better understanding of the relationships between different taxa within the neoophoran Platyhelminthes (Gremini \& Falleni, 1998) including Cestoda (Świderski \& Mackiewicz, 1976; Świderski \& Xylander, 2000; Bruňanská et al., 2005; Poddubnaya et al., 2006, 2012; Levron et al., 2007). The structure and composition of eggshell-forming globules in vitellocytes have been considered to be especially phylogenetically informative (Gremigni \& Falleni, 1991; Falleni et al., 2001).

To date, limited data are available on vitellogenesis in the Caryophyllidea, one of the basal groups of the Eucestoda. Out of about 150 species of four currently recognised families (Mackiewicz, 1994; Oros et al., 2008) seven members belonging to the two families (Caryophyllaeidae, Lytocestidae) were studied, namely Archigetes sieboldi (by Poddubnaya et al., 2003; Bruňanská et al., 2012b), Caryophyllaeus laticeps (Pallas, 1781) (by Ortner-Schönbach, 1913; Mackiewicz, 1968; Świderski et al., 2004a; Bruňanská et al. 2010), Caryophyllaeides fennica (by Mackiewicz, 1968), Glaridacris catostomi (by Świderski \& Mackiewicz, 1976), Wenyonia virilis (by Świderski et al., 2009), Atractolytocestus huronensis (by Bruňanská et al., 2009), Khawia armeniaca (by Świderski et al., 2004b) and Monobothrioides chalmersius (by Arafa 2012). As far as $C$. laticeps is concerned, the first histological and histochemical investigation on vitellogenesis was based on light microscopy (Mackiewicz, 1968), and supplemented by ultrastructural data in two brief abstracts (Świderski et al., 2004a, Bruňanská et al., 2010). The latter reported lipid droplets, never found previously in vitellocytes of the Caryophyllidea.

The purpose of the present paper is to give detailed information on the ultrastructure of vitellaria, developing vitellocytes and vitelloduct of $C$. laticeps, the oldest fish tapeworm parasitizing a wide spectrum of cypriniform fishes in the Palaearctic region (Scholz et al., 2011). These data 
may extend our current knowledge on reproductive biology and evolutionary history of the Caryophyllidea.

\section{Materials and methods}

Adult specimens of the caryophyllidean cestode Caryophyllaeus laticeps (Pallas, 1781) were collected from the intestine of bream, Abramis brama (Pisces: Cyprinidae), from Rybinsk Reservoir, Yaroslavl Province, Russia. The worms were cut into small pieces, fixed immediately in ice cold $3 \%$ glutaraldehyde in sodium cacodylate buffer $(\mathrm{pH}$ 7.4) for $3-8 \mathrm{~h}$, followed by 3 changes of cacodylate buffer, and postfixed in $1 \% \mathrm{OsO}_{4}$ for $2 \mathrm{~h}$. Material was dehydrated in a graded ethanol series, and embedded in Araldite. Ultrathin sections $(60-70 \mathrm{~nm})$ were cut using a Leica Ultracut UCT ultramicrotome, placed on copper grids and double-stained with uranyl acetate and lead citrate. The grids were examined in a JEOL 1010 transmission electron microscope operated at $80 \mathrm{kV}$.

The periodic acid-thiosemicarbazide-silver proteinate (PATSC-SP) technique of Thiéry (1967) was applied to determine specific cytochemical localisation of glycogen at the ultrastructural level.

\section{Results}

Vitellaria of $C$. laticeps are situated in lateral and median bands in the medullary parenchyma of a non-segmented (monozoic) strobila (Fig. 1A; Mackiewicz, 1968), where they occur in preovarian and postovarian positions. Vitellaria consist of numerous oval or lobate follicles (Figs. 1,2) of various sizes. They are interconnected by small collecting ducts, two larger lateral ducts that connect and form a major transverse vitelline duct that connects the vitellarium to the ootype.

Each vitelline follicle is composed of vitelline cells at various stages of development in a matrix of interstitial tissue (Fig. 3).

\section{Interstitial tissue}

Interstitial tissue extends between vitellocytes within the vitellarium (Figs. 3, 4) and surrounds the follicles periphery. The nuclei of the interstitium occur either between vitellocytes (Fig. 3), or at the periphery of the vitelline follicle (Fig. 4). They contain an electron-dense nucleolus and scattered clumps of heterochromatin. The periphery of the nucleus is bordered by a thin layer of electron-dense chromatin. The perinuclear cytoplasm of the interstitial tissue contains granular endoplasmic reticulum and vesicles of various size and density (Fig. 4).

\section{Vitellocytes}

Four stages (I - IV) can be recognized during differentiation of the vitellocytes: (I) immature, (II) early maturation, (III) advanced maturation, and (IV) mature (Fig. 3).

\section{Immature (I)}

Immature vitelline cells are localised at the follicular pe- riphery. They have a large nucleus with distinct nucleolus and show a high nucleo-cytoplasmic ratio (Fig. 5). Irregular clumps of dense chromatin occur in the nucleoplasm. Several small mitochondria and more abundant ribosomes are present in the cytoplasm.

\section{Early maturation (II)}

The most characteristic feature of the vitellocytes at this stage (Fig. 2) is the small electron-dense vesicles that are the earliest form of shell globules (Fig. 6). Formation of electron-dense vesicles is associated with Golgi complexes and endoplasmic reticulum (Fig. 7). The endoplasmic reticulum consists of short rows of smooth membranes and long parallel cisternae.

\section{Advanced maturation (III)}

The maturation of cells is characterized by an increase in size, decrease of the nucleo-cytoplasmic ratio, development of endoplasmic reticulum and Golgi complexes, formation of shell globule clusters and glycogen, and nuclear and nucleolar transformation (Fig. 3). Extensive cisternae of endoplasmic reticulum and Golgi complexes continue in producing single shell globules (Fig. 8) and shell globule clusters (Fig. 9). Minute secretory vesicles fuse and form secretory globules, which join together to form shell globule clusters. Initially, electron-dense shell globules are loosely packed in electron-lucent matrix of shell globule clusters (SGCa, Figs. 10, 11). Later, shell globule clusters are built of tightly packed globules ( $\mathrm{SGCb}$, Figs. 12 - 19, 21, 22).

The shape of the nucleus changes from oval (Fig. 8) to lobate (Figs. 10, 11). It occupies a central region of the cell. The nucleoplasm includes numerous clumps of condensed chromatin (Fig. 11). In more advanced stages of vitellogenesis, glycogen particles stained with PA-TSC-SP form islands of various sizes in the nucleus (Figs. 12, 13). Moderately electron-dense cytoplasm may contain electron-lucent amorphous parts with scattered glycogen granules (Figs.11 - 13). Occasionally, single lipid droplets have been observed in developing vitellocytes (Fig. 14).

\section{Mature (IV)}

The oval mature vitellocyte measures about $25 \mu \mathrm{m}$ in diameter. Its nucleus and cytoplasm are filled with glycogen (Fig. 15, 16). Nucleolus and chromatin material are displaced towards the nuclear periphery (Fig. 15). Amorphous vitelline cytoplasm is filled with shell globules and shell globule clusters. The later are represented by tightly packed electron-dense globules within matrix of moderate electrondensity (SGCb, Figs. 15, 16).

In addition to the vitelline material described above, single osmiophobic lipid droplets have been observed occasionally in mature vitellocytes (Figs. 17 - 19). They are localised either in the perinuclear cytoplasm (Fig. 17), at the periphery of the cell (Fig. 18), or irregularly scattered in the cytoplasm (Fig. 19). 

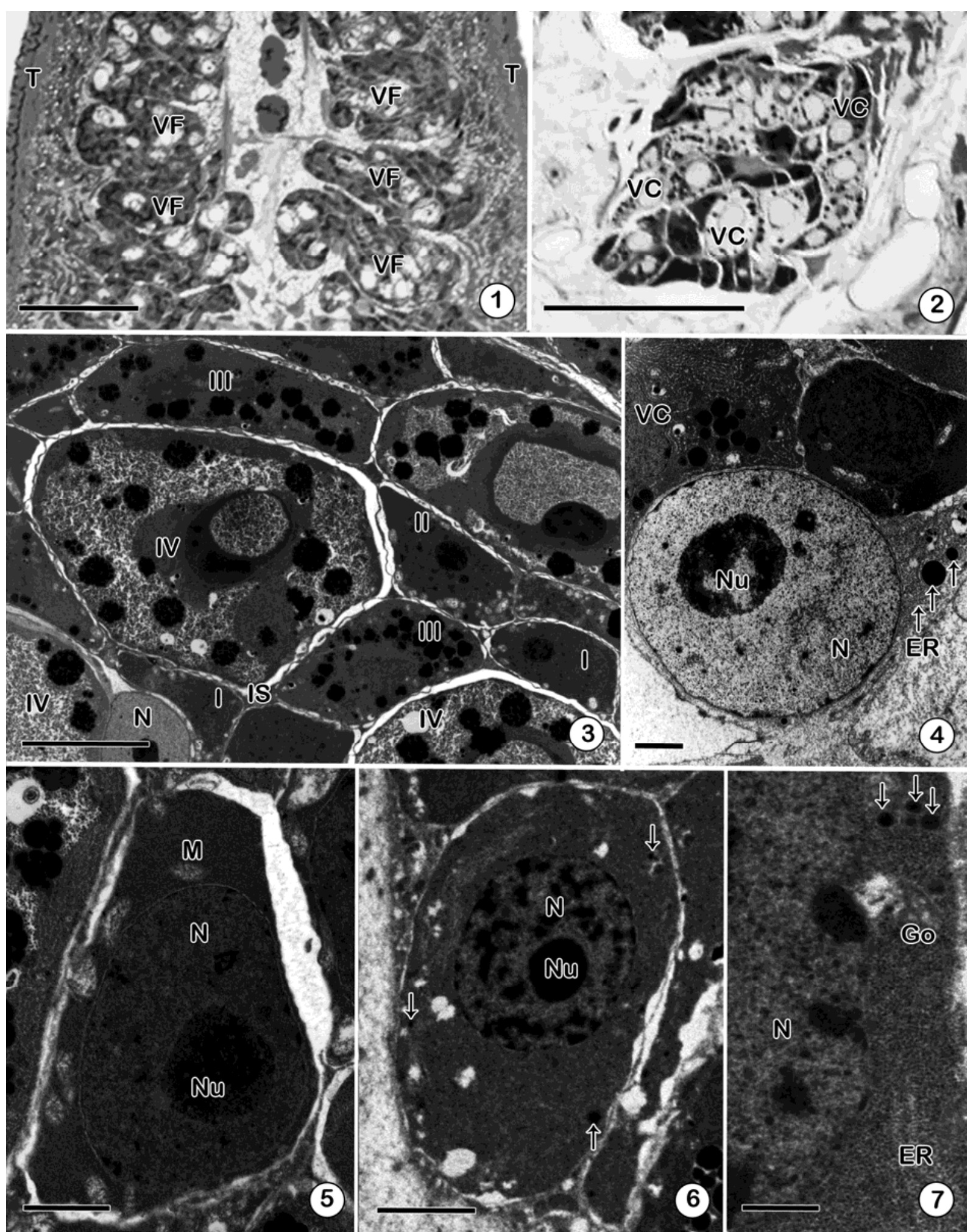

Figs. 1 - 7. Overview of the vitelline follicles in C. laticeps. Details of immature vitelline cells (I) and vitellocytes at early stage of maturation (II).

(1) General view of vitellarium of Caryophyllaeus laticeps in semithin transverse section. T - tegument, VF - vitelline follicles. Bar $=100 \mu \mathrm{m}$;

(2) Vitelline follicle in semithin transverse section. $\mathrm{VC}$ - vitellocyte. Bar $=100 \mu \mathrm{m}$; (3) Tangential section through a vitelline follicle of $C$. laticeps showing vitellocytes at various stages of development. I - immature vitellocytes, II - early maturing vitellocytes, III - advanced maturing vitellocytes, IV - mature vitellocytes, IS - interstitial tissue, $\mathrm{N}$ - nucleus of the IS. Bar $=10 \mu \mathrm{m}$; (4) Nucleus (N) of an interstitial tissue at the periphery of vitelline follicle. arrows - electron-dense vesicles, $\mathrm{ER}$ - endoplasmic reticulum, $\mathrm{Nu}$ - nucleolus, $\mathrm{VC}$ - vitelline cell. $\mathrm{Bar}=2 \mu \mathrm{m}$; (5) Immature vitellocyte (I). $\mathrm{N}$ - nucleus, $\mathrm{Nu}$ - nucleolus, $\mathrm{M}$ - mitochondrion. Bar $=2 \mu \mathrm{m}$; (6) Early maturing vitellocyte (II), and formation of small electron-dense vesicles (arrows). $\mathrm{N}$ - nucleus, $\mathrm{Nu}$ - nucleolus. Bar $=3.3 \mu \mathrm{m}$; (7) Vitelline cytoplasm of early maturing vitellocyte (II) showing endoplasmic reticulum (ER) and Golgi (Go) with a small electron-dense vesicles (arrows). Bar $=0.7 \mu \mathrm{m}$. 


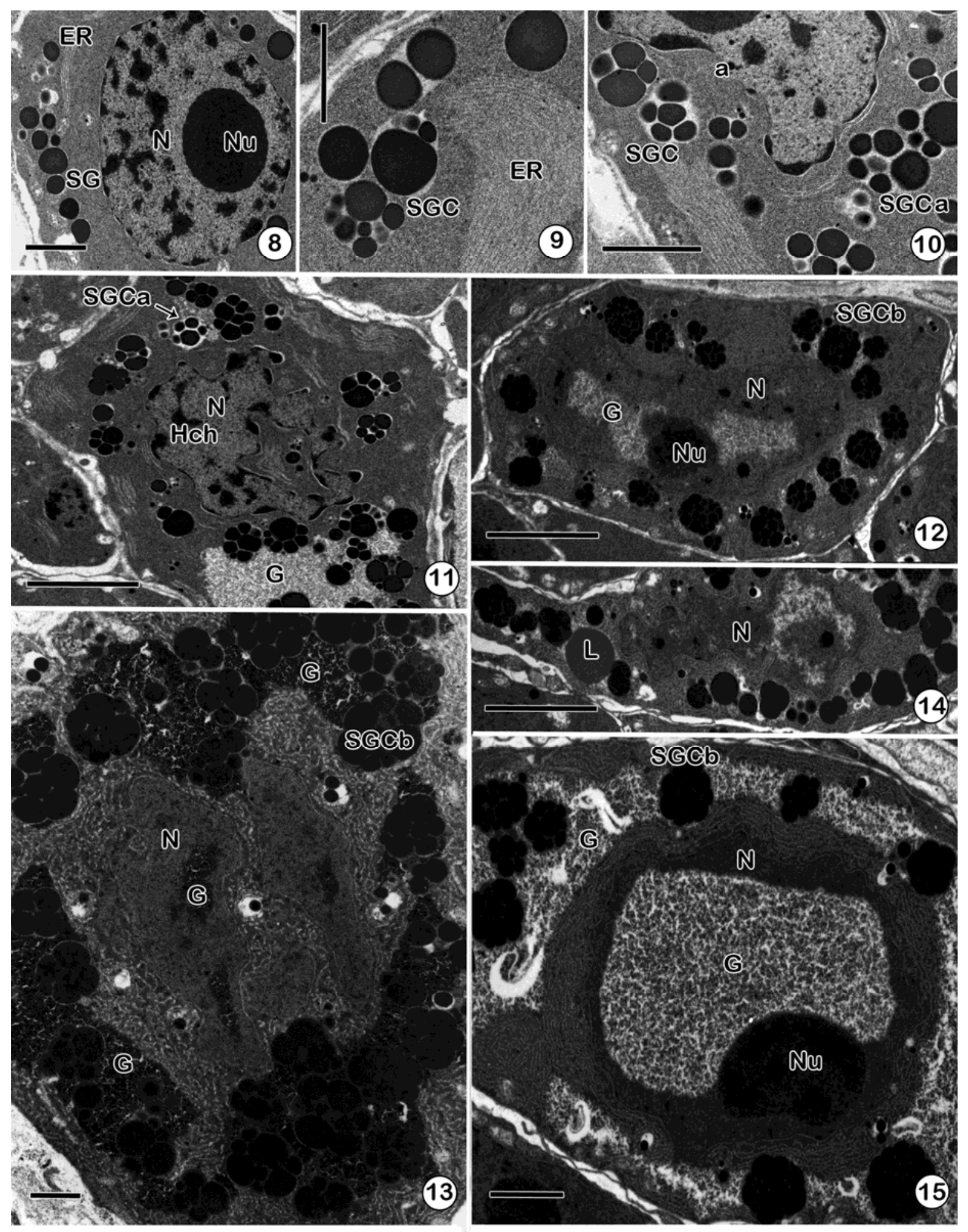

Figs. 8 - 15. Vitelline cells at advanced stage of maturation (III).

(8) Advanced maturing vitellocyte (III) and various stages of electron-dense shell globule formation (SG). ER - endoplasmic reticulum, $\mathrm{N}$ - nucleus, $\mathrm{Nu}$ - nucleolus. $\mathrm{Bar}=2 \mu \mathrm{m}$; (9) Detail of the periphery of the advanced maturing vitellocyte (III) showing formation of shell globule clusters (SGC). ER - endoplasmic reticulum. Bar $=2 \mu \mathrm{m}$; (10) Shell globule clusters with electron-lucent matrix and loosely packed shell globules (SGCa) in advanced maturing vitellocyte (III). ER - endoplasmic reticulum, $\mathrm{N}$ - nucleus. Bar $=2 \mu \mathrm{m}$; (11) Cytoplasm of advanced maturing vitellocyte (III) contains electronlucent area filled with dense granules of glycogen (G). Hch - heterochromatin, N - nucleus, SGCa - shell globule clusters with electron-lucent matrix and loosly packed shell globules. Bar $=6 \mu \mathrm{m}$; (12) Intranuclear glycogen (G) in maturing vitellocytes (III). $\mathrm{N}$ - nucleus, $\mathrm{Nu}$ - nucleolus, $\mathrm{SGCb}$ - shell globule clusters composed of tightly packed shell globules embedded within matrix of moderate electrondensity. Bar $=6 \mu \mathrm{m}$; (13) Visualisation of glycogen $(\mathrm{G})$ in maturing vitellocytes (III) by Thiéry method. $\mathrm{N}$ - nucleus, SGCb - shell globule clusters.Bar $=1 \mu \mathrm{m}$; (14) Lipid droplet (L) in perinuclear region of a maturing vitellocyte (III). N- nucleus. Bar $=6 \mu \mathrm{m}$; (15) The amount of intranuclear and intracytoplasmic glycogen $(\mathrm{G})$ increases with maturing of vitellocytes (III). $\mathrm{N}$ - nucleus, $\mathrm{Nu}-$ nucleolus, $\mathrm{SGCb}-$ shell globule clusters. Bar $=3 \mu \mathrm{m}$. 
Vitellocytes within the vitelloduct

Mature vitellocytes from the vitelloducts are not identical to those of the vitelline follicles (Fig. 20). In addition to a nucleus, tightly packed shell globule clusters (SGCb), glycogen and lipid droplets (very rarely), the cytoplasm of mature vitellocytes from the vitelloduct (Fig. 22, inset) has additional single bodies with dense spiral or concentric lamellar configuration. These lamellar bodies, absent from vitellocytes within the follicle, measure approximately $0.8 \mu \mathrm{m}$. The wall of the vitelloduct is built by flat epithelium (Figs. 20, 23) lined with cilia of 9+2 configuration (Fig. 23). The axonemes of the cilia are attached with their basal bodies. volves a continuous increase in cell size, an extensive development of cell components engaged in shell globule production, and formation of the so-called "nuclear vacuole", a very specific feature in the Caryophyllidea. Significant differences, however, exist with regard to the presence/absence of the interstitial tissue in the vitelline follicles, and the occurrence of vitelline inclusions, namely lipids, and lamellar bodies.

Interstitial tissue has not been described previously in $C$. laticeps. This component is present in vitelline follicles of some caryophyllidean tapeworms (see Świderski \& Mackiewicz, 1976; Bruňanská et al., 2009; Świderski et
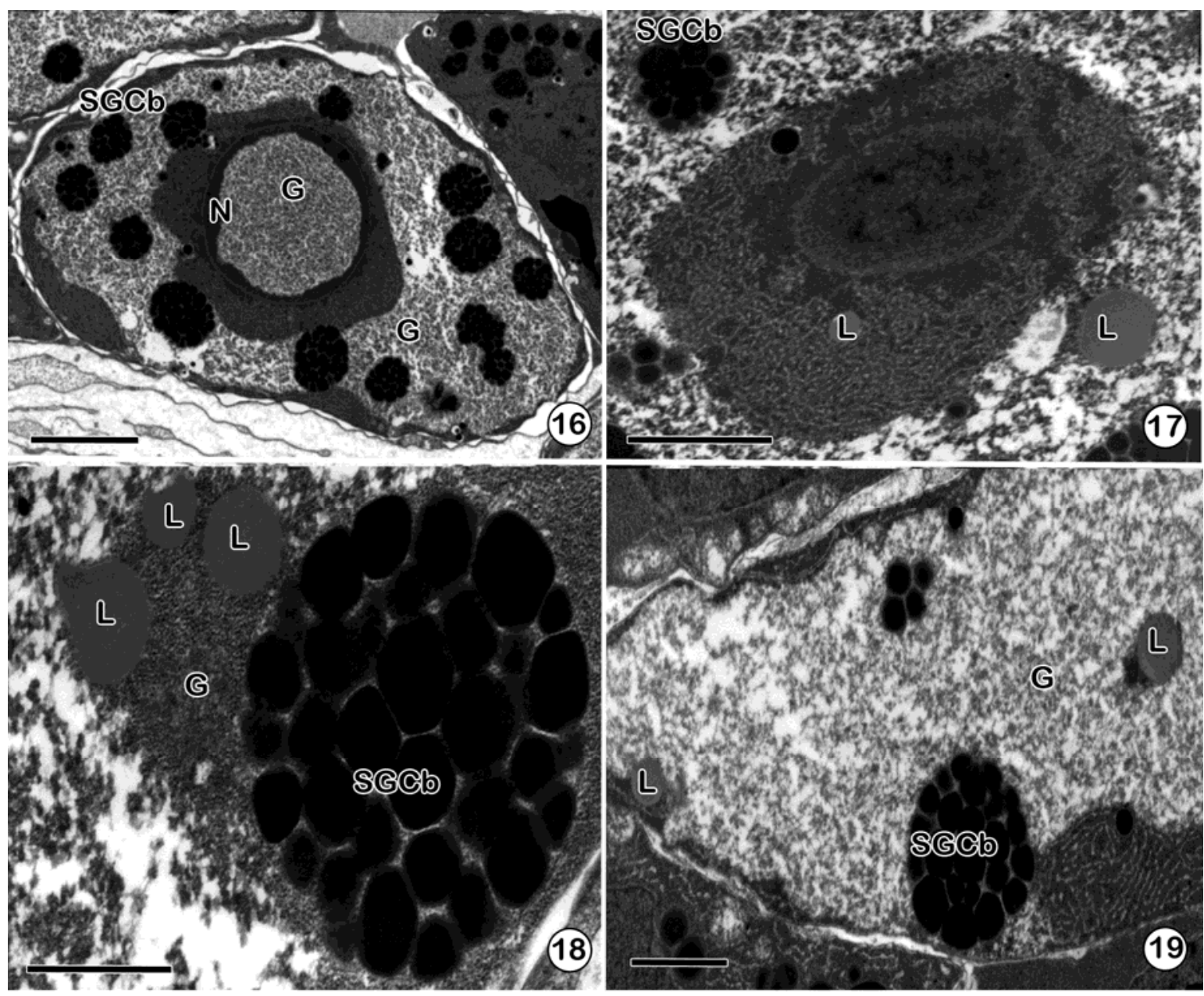

Figs. 16 - 19. Mature vitelline cells (IV) from the vitelline follicles

(16) Cytoplasm and nucleus (N) of mature vitellocytes (IV) are packed with glycogen (G). Remnants of an electron-dense cytoplasm are concentrated in the perinuclear region and at periphery of the cell. $\mathrm{N}$ - nucleus, SGCb - shell globule clusters. Bar $=5 \mu \mathrm{m} ;(17) \mathrm{Lipid}$ droplets $(\mathrm{L})$ in perinuclear region of a mature vitellocyte. SGCb - shell globule cluster. Bar $=2 \mu \mathrm{m}$; (18) Detail of lipid droplets (L) and shell globule cluster (SGCb) at periphery of the mature vitellocyte (IV). G - glycogen. Bar $=1 \mu \mathrm{m}$; (19) Scattered lipid droplets (L) in cytoplasm of the mature vitellocyte (IV). G - glycogen, SGCb - tightly packed shell globule cluster. Bar $=2 \mu \mathrm{m}$.

\section{Discussion}

The general pattern of vitellocyte differentiation and ultrastructure in $C$. laticeps resembles that previously reported for this species and/or other caryophyllideans (Mackiewicz, 1968; Świderski \& Mackiewicz, 1976; Świderski et al., 2004a, 2004b, 2009). Vitellogenesis in- al., 2009; Bruňanská et al., 2012b; Arafa 2012; present study). Interstitial tissue has been proposed to be involved in selection and distribution of nutrients transported from the parenchyma toward the vitellocytes of some cestodes (Xylander, 1988; Bruňanská et al., 2009), and monogeneans (Halton et al., 1974). In addition to the caryophyllideans, interstitial tissue has been observed also in spatheboth- 

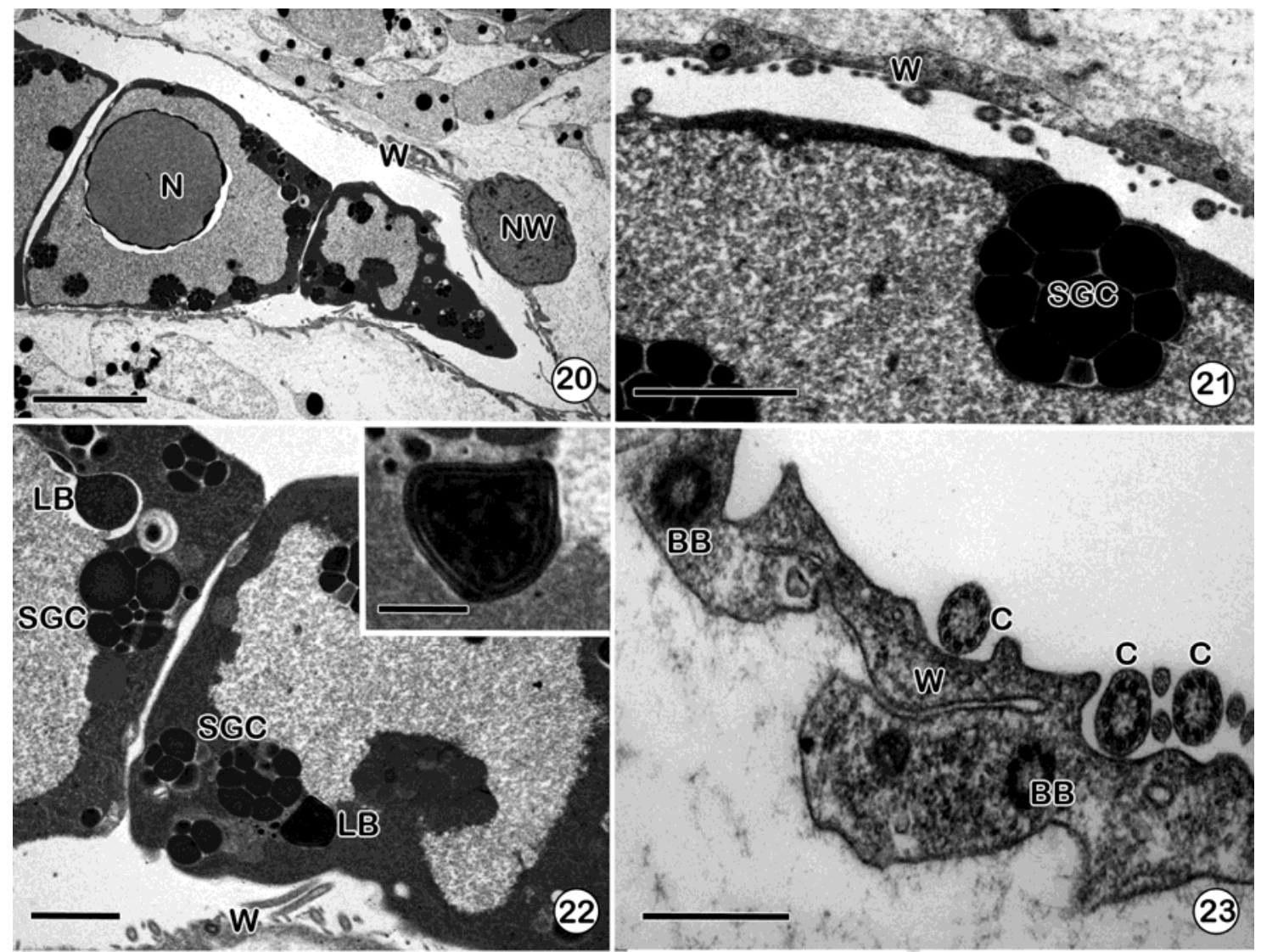

Figs. 20 - 23. Mature vitelline cells (IV) from vitelloduct and ultrastructure of the wall of the vitelloduct.

(20) Vitellocytes in vitelloduct. N - nucleus of vitellocyte, NW - nucleus of epithelial wall of the vitelloduct, SGCb - shell globule clusters, W wall of the vitelloduct. Bar $=10 \mu \mathrm{m}$; (21) Detail of membrane-bound shell globule clusters (SGCb) in vitellocytes from the vitelloduct. W - the wall of vitelloduct. Bar $=2 \mu \mathrm{m}$; (22) The lamellar bodies (LB) within cytoplasm of the mature vitellocytes in the vitelloduct. SGCb - shell globule clusters, $\mathrm{W}-$ wall of vitelloduct with traces of cilia. Bar $=2 \mu \mathrm{m}$. Inset: detail of lamellar body (LB). Bar $=0.55 \mu \mathrm{m}$; $(23)$ Detail of the epithelial wall $(\mathrm{W})$ of vitelloduct. $\mathrm{BB}-$ basal body of cilium, $\mathrm{C}-$ cilium. $\mathrm{Bar}=0.5 \mu \mathrm{m}$.

riideans (Bruňanská et al., 2005; Poddubnaya et al., 2006), bothriocephalideans (Korneva, 2001; Levron et al., 2007; Świderski et al., 2011a), trypanorhynchs (Świderski et al., 2006b; 2012), nippotaeniideans (Korneva, 2002), and proteocephalideans (Korneva \& Davydov, 2001). Interstitial cells may also occur in some trypanorhynchs (Świderski et al., 2006a, 2007, 2012).

In the present study, mature vitellocytes of $C$. laticeps contain four types of vitelline material (shell globule/ shell globule clusters, glycogen, lipids, lamellar bodies), thus resembling $A$. sieboldi (Bruňanská et al., 2012b). In contrast, only three types of vitelline inclusions (shell globules/shell globule clusters, glycogen, lipid droplets) were previously described in $C$. laticeps in a brief abstract (Bruňanská et al., 2010). Three different types of vitelline material (shell globules/shell globule clusters, glycogen, "lamellar" granules $\{=$ lamellar bodies, present paper $\}$ ) have been found in the triploid A. huronensis (Bruňanská et al., 2009). Two types of vitelline material (shell globule clusters and glycogen) have been reported in the light microscope study on the histology/histochemistry of vitellogenesis of $C$. laticeps and Caryophyllaeides fennica by Mackiewicz (1968), in a brief abstract of an ultrastructural study of C. laticeps by Świderski et al. (2004a), and in ultrastructural studies of some caryophyllideans (Świderski \& Mackiewicz, 1976; Świderski et al., 2004b).

It should be noted that the ultrastructural data above are from species in two families: Caryophyllaeidae and Lytocestidae. Recent studies of vitellogenesis from Monobothrioides chalmerius of the family Lytocestidae by Arafa (2012), however, have reported five kinds of vitelline cell inclusions: shell globule clusters, glycogen, lipid droplets, translucent vesicles and electrondense vesicles. The significance of these differences within and between families is unclear and may be elucidated only with more extensive sampling of all stages of vitellogenesis in caryophyllidean cestodes from all of the four families.

Shell globule clusters in the maturing vitellocytes of $C$. laticeps are primarily of two forms that represent early and later stages of cluster development. Similar finding has been described in the caryophyllidean A. huronensis (Bruňanská et al., 2009). The first form (loosely packed electron-dense shell globules situated in electron-lucent matrix) occurs in the initial stages of shell globule cluster formation of $C$. laticeps. This form of shell globule cluster appears to be characteristic for the mature vitellocytes of most primitive tapeworms (Xylander, 1987, 1988), some caryophyllideans (Poddubnaya et al., 2003; Świderski et 
al., 2004b), spathebothriideans (Bruňanská et al., 2005; Poddubnaya et al., 2006) and/or pseudophyllideans (Świderski \& Mokhtar, 1974; Korneva, 2001; Levron et al., 2007). The second form (tightly packed shell globules embedded in matrix of moderate electrondensity) is found in caryophyllideans (Świderski \& Mackiewicz, 1976; Świderski et al., 2004a; Bruňanská et al., 2012b; present study), and spathebothriideans (Bruňanská et al., 2005; Poddubnaya et al., 2006).

The lack of cytoplasmic lipid droplets and the large amount of glycogen have been consisdered to be the most characteristic features of vitellocytes in the Caryophyllidea (Świderski \& Xylander, 2000). However, recent investigations have revealed the presence of lipid droplets in the mature vitellocytes of some caryophyllideans, e.g. A. sieboldi (Bruňanská et al., 2012b), C. laticeps (Bruňanská et al., 2010; present study) and Monobothrioides chalmersius (Arafa, 2012). In addition, lipid droplets were also described from mature vitellocytes of the triploid A. huronensis in a brief abstract (Bruňanská et al., 2007), in degenerating vitellocytes within intrauterine eggs of caryophyllideans Wenyonia virilis (Młocicki et al., 2010) and Khawia sinensis (Bruňanská et al., 2012a). Lipid droplets have been detected in the maturing vitellocytes (stage III) of $C$. laticeps (present study) and in the mature vitellocytes (stage IV) of A. sieboldi (Bruňanská et al., 2012b) and Monobothrioides chalmersius (Arafa, 2012). They are osmiophobic and electron-lucent, a feature being indicative of saturated lipids (Świderski \& Xylander, 2000). The presence of saturated lipid droplets has been also described in amphilinideans, gyrocotylideans (Xylander, 1987; 1988), spathebothriideans (Bruňanská et al., 2005; Poddubnaya et al., 2006), bothriocephalideans (Świderski \& Mokhtar, 1974; Korneva, 2001, Levron et al., 2007), tetraphyllideans (Mokhtar-Maamouri \& Świderski, 1976), trypanorhynchs (Świderski et al., 2006a, b, 2007, 2012), diphyllideans (Świderski et al., 2011b), and/or proteocephalideans (Bruňanská, 1997, 1999). Given that lipids in the developing vitellocytes of caryophyllidans have been detected only very rarely, it is possible that their role in embryogenesis may be more variable than previously supposed (Bruňanská et al., 2012b).

Lamellar bodies were found for the first time in vitelline cells from the vitelloduct in $C$. laticeps. These single dense components with spiral or concentric lamellar configuration have been detected previously in the mature vitellocytes from vitelline follicles of $A$. huronensis (Bruňanská et al., 2009), K. sinensis (Bruňanská et al., 2010), A. sieboldi (Bruňanská et al., 2012b), and vitellocytes within intrauterine eggs of $W$. virilis (Młocicki et al., 2011), K. sinensis (Bruňanská et al., 2012a), or A. sieboldi (Bruňanská et al., 2012b). This latter study indicates that lamellar bodies may be formed either during gradual transformation of shell globule/shell globule clusters or from the breakdown of granular endoplasmic reticulum in the mature vitellocytes. The current study on $C$. laticeps supports a close relation between lamellar bodies and the breakdown of granular endoplasmic reticulum. Lamellar bodies have been proposed to be involved in glycoprotein synthesis and/or the formation of foci of cytoplasmic degradation (lamellar bodies = "GER-bodies" of Młocicki et al., 2011). On the other hand, according to Poddubnaya et al. (2006) 'concentric bodies' (= lamellar bodies, present paper) in the spathebothriidean cestode Didymobothrium rudolphii represent a phase in vitelline globule transformation during the process of egg shell formation.

Ultrastructural characters of the vitellocytes in the Caryophyllidea, as exemplified by the mass of glycogen in the nucleus, for example, are closely related to the nature of their life-history (Mackiewicz, 1981). The occurence of lipid droplets and lamellar bodies in the vitellocytes of $C$. laticeps (present study), and A. sieboldi (Bruňanská et al., 2012 b) indicates that vitellogenesis within the Caryophyllidea is more complex than previously thought. Further investigations into vitellogenesis and fertilisation of other caryophyllideans and related cestodes are needed to provide additional ultrastructural data for elucidation of the reproductive biology and evolutionary history of the lower tapeworms.

\section{Acknowledgements}

We would like to thank Dr. Larisa G. Poddubnaya, Institute of Biology of Inland Waters, Russian Academy of Sciences, Borok, Yaroslavl Region 152742, Russia, for kindly providing us with material for the present study. We are grateful to the staff of the Laboratory of Electron Microscopy, Institute of Parasitology, BC AS CR, České Budějovice, Czech Republic for excellent technical assistance. This study was supported by the Grant Agency of the Slovak Republic VEGA (project no. 2/0047/11), and the Slovak Research and Development Agency (project no. APVV-0653-11). The work was realized within a frame of Centre of Excellence for Parasitology (Code ITMS: 26220120022) based on the support of the Operational Programme "Research \& Development" funded from the European Regional Development Fund (rate 0.1).

\section{References}

ARAFA, S. Z. (2012): Light and electron microscopic study on vitellogenesis of the caryophyllidean cestode Monobothrioides chalmersius (Woodland, 1924) Hunter, 1930 (Lytocestidae) from the catfish Clarias gariepinus. J. Basic Appl. Zool., 65: 125 - 132. DOI: 10.1016/j.jobaz.2012.07.007

BRUŇANSKÁ, M. (1997): Proteocephalus exiguus La Rue 1911 (Cestoda, Proteocephalidae): ultrastructure of the vitelline cells. Helminthologia, 34: $9-13$

BRUŇANSKÁ, M. (1999): Ultrastructure of primary embryonic envelopes in Proteocephalus longicollis (Cestoda, Proteocephalidea). Helminthologia, 36: 83 - 89

BRuŇANSKÁ, M., DrobníKOvÁ, P., Oros M. (2007): Vitellocytes of the caryophyllidean cestode Atractolytocestus huronensis. In: Programme and Abstracts of the 10th International Helminthological Symposium, September 9 14, 2007, Stará Lesná, High Tatras, Slovak Republic, p. 14 
BRUŇANSKÁ, M., DrobníkOVÁ, P., Oros M. (2009): Vitellogenesis in the cestode Atractolytocestus huronensis Anthony, 1958 (Caryophyllidea: Lytocestidae). Parasitol. Res., 105: 647 - 654. DOI: 10.1007/s00436-009-1436-7

BRUŇANSKÁ, M., DrobNíKOVÁ, P., Oros, M., Poddubnaya, L. G., HanzelovÁ, V. (2010): Caryophyllidea: comparative ultrastructure of the vitellocytes. In Abstracts of the XIIth International Congress of Parasitology (ICOPA), 15 - 20th August 2010, Melbourne, Australia, pp. $833-834$

BruŇANSKÁ, M., MACKIEWICZ, J. S., MŁocicki, D., ŚWIDERSKI, Z., NEBESÁŘOVÁ, J. (2012a): Early intrauterine embryonic development in Khawia sinensis Hsü, 1935 (Cestoda, Caryophyllidea, Lytocestidae), an invasive tapeworm of carp (Cyprinus carpio): an ultrastructural study. Parasitol. Res., 110: 1009 - 1017. DOI: 10.1007/s00436011-2590-2

BruŇAnskÁ, M., MACKIEWICZ, J. S., NebesÁR̆ovÁ, J. (2012b): Vitellogenesis in Archigetes sieboldi Leuckart, 1878 (Cestoda, Caryophyllidea, Caryophyllaeidae), an intestinal parasite of carp (Cyprinus carpio L.). Histol. Histopathol., 27 (12): 1611 - 1620

BruñAnskÁ, M., Poddubnaya, L. G., Dezfuli B. S. (2005): Vitellogenesis in two spathebothriidean cestodes. Parasitol. Res., 96: 390 - 397. DOI: 10.1007/s00436-0051378-7

Falleni, A., Lucchesi, P., Gremigni, V. (2001): The ultrastructure of oocyte and vitellocyte inclusions in a scutariellid (Platyhelminthes, Rhabdocoela, Temnocephalida) with phylogenetic implications. Belg. J. Zool., 131 (Suppl): $187-189$

GREMIGNI, V., FALLENI, A. (1991): Ultrastructural features of cocoon-shell globules in the vitelline cells of neoophoran platyhelminths. Hydrobiologia, 227: 105 - 111. DOI: 10.1007/BF00027589

GREMigni, V., FALleni, A. (1998): Characters of the female gonad and the phylogeny of Platyhelminthes. Hydrobiologia, 383: 235 - 242. DOI: 10.1023/A:1003413627495 Halton, D. W., StRanOCK, S. D., HardCASTle, A. (1974): Vitelline cell development in monogenean parasites. $Z$. Parasitenkd., 45: 45 - 61. DOI: 10.1007/BF00636526

KoRNEVA, J. V. (2001): Vitellogenesis and capsule formation during embryogenesis in Triaenophorus nodulosus (Cestoda, Pseudophyllidea, Triaenophoridae). Zool. Zh., 80: $1422-1428$

KORNEVA, J. V. (2002): Fine structure of reproductive system in Nippotaenia mogurndae (Cestoda, Nippotaeniidea). Zool. Zh., 81: $266-275$

Korneva, J. V., Davydov, V. G. (2001): The female reproductive system in the proteocephalidean cestode Gangesia parasiluri (Cestoda, Proteocephalidea, Proteocephalidae). Zool. Zh., 80: 131 - 144

Levron, C., Poddubnaya, L. G., Kuchta, R., Freeman, M., SCHOLZ, T. (2007): Vitellogenesis and vitelline system in the pseudophyllidean tapeworm Paraechinophallus japonicus: ultrastructural and cytochemical studies. Folia Parasitol., 54: 43 - 50

MACKIEWICZ, J. S. (1968): Vitellogenesis and eggshell formation in Caryophyllaeus laticeps (Pallas) and Caryophyllaeoides fennica (Schneider) (Cestoidea: Caryophyllidea). Z. Parasitenkd., 30: 18 - 32

MACKIEwICZ, J. S. (1982): Caryophyllidea (Cestoidea): evolution and classification. Adv. Parasitol., 19: 139- 206. DOI: 10.1016/S0065-308X(08)60267-5

MACKIEWICZ, J. S. (1994): Order Caryophyllidea van Beneden in Carus, 1863. In: KhALIL, L. F., JonES, A., BRAY, R. A. (Eds) Keys to the cestode parasites of vertebrates. CAB International Wallingford, Oxon, p. $21-43$ MŁocICKI, D., ŚWIDERSKI, Z, MACKIEWICZ, J. S., IBRAHEEM, M. H. (2010): Ultrastructure of intrauterine eggs: evidence of early ovoviviparity in the caryophyllidean cestode Wenyonia virilis Woodland, 1923. Acta Parasitol., 55: 349 - 358. DOI: 10.2478/s1 1686-010-0044-0

MŁocICKI, D., ŚWIDERSKI, Z., MACKIEWICZ, J.S., IBRAHEEM, M. H. (2011): Ultrastructural and cytochemical studies of GER-bodies in the intrauterine eggs of Wenyonia virilis Woodland, 1923 (Cestoda, Caryophyllidea). Acta Parasitol., 56: 40 - 47. DOI: 10.2478/s11686-0110011-4

MOKHTAR-MAAMOURI, F., ŚwIDERSKI, Z. (1976): Vitellogenese chez Echeneibothrium beauchampi Euzet 1959 (Cestoda: Tetraphyllidea, Phyllobothriidae). Z. Parasitenkd., 50: 293-302

Oros, M., Hanzelová, V., Scholz, T., Mackiewicz, J. S. (2008): Phylogenetic relationships of the monozoic tapeworms (Eucestoda:Caryophyllidea)) inferred from morphological characters. Syst. Parasitol., 70: 1 - 14. DOI: 10.1007/s11230-008-9133-y

ORTNER-SCHÖNBACH，P. (1913): Zur Morphologie des Glykogens bei Trematoden und Cestoden. Arch. Zellforsch., 11: 413 - 449

PoddubnayA, L. G., BRUŇANSKÁ, M., ŚWIDERSKI, Z., GIBSON, D. I. (2012): Ultrastructure of the vitellarium in the digeneans Phyllodistomum angulatum (Plagiorchiida: Gorgoderidae) and Azygia lucii (Strigeida: Azygiidae). Acta Parasitol., 57: 235 - 246. DOI: 10.2478/s11686-0120030-9

Poddubnaya, L. G., Gibson, D. I., Świderski, Z., Olson, P. D. (2006): Vitellocyte ultrastructure in the cestode Didymobothrium rudolphi (Monticelli, 1890): possible evidence for the recognition of divergent taxa within the Spathebothriidea. Acta Parasitol., 51: 255 - 263. DOI: 10.2478/s11686-006-0039-z

Poddubnaya, L. G., Mackiewicz, J. S., Kuperman, B. I. (2003): Ultrastructure of Archigetes sieboldi (Cestoda: Caryophyllidea): relationship between progenesis, development and evolution. Folia Parasitol., 50: 275 - 293 Scholz, T., Brabec, J., KrÁlová-HromadovÁ, I., Oros, M., BazSAlovicsovÁ, E., ERmolenKo, A., HANZElovÁ, V. (2011): Revision of Khawia spp. (Cestoda: Caryophyllidea), parasites of cyprinid fish, including a key to their identification and molecular phylogeny. Folia Parasitol., 58: $197-223$

ŚWiderski, Z., BruñanskÁ, M., Poddubnaya L. G. (2004a): Ultrastructural and cytochemical studis on vitellogenesis in the caryophyllidean cestode Caryophyllaeus 
laticeps. In Programme and Abstracts of the $9^{\text {th }}$ European Multicolloquium of Parasitology, 18 - 23 July 2004, Valencia, Spain, p. 602

Świderski, Z., BruŇAnskÁ, M., Poddubnaya, L. G., MACKIEWICZ, J. S. (2004b): Cytochemical and ultrastructural study on vitellogenesis in caryophyllidean cestode Khawia armeniaca (Cholodkovski, 1915). Acta Parasitol., 49: $16-24$

Świderski, Z., Gibson, D. I., MARigo, A. M., Delgado, E., Torres, J., MiQuel, J. (2011a): Ultrastructure and cytochemistry of vitellogenesis and the vitellocytes of the bothriocephalidean cestode Clestobothrium crassiceps (Rudolphi, 1819), a parasite of the teleost fish Merluccius merluccius (L., 1758) (Gadiformes, Merlucciidae). Acta Parasitol., 56: 392 - 405. DOI: 10.2478/s11686-011-0071-5

ŚWIDERSKI, Z., MACKIEWICZ, J. S. (1976): Electron microscope study of vitellogenesis in Glaridacris catostomi (Cestoidea: Caryophyllidea). Int. J. Parasitol., 6: $61-73$. DOI: 10.1016/0020-7519(76)90011-4

Świderski, Z., Mackiewicz, J. S., Eira, C., Miquel, J. (2011b): Ultrastructural and cytochemical study on vitellogenesis in the diphyllidean cestode Echinobothrium euterpes (Echinobothriidae) and its phylogenetical implications. Acta Parasitol., 56: 180 - 190. DOI: 10.2478/s11686-0110027-9

Świderski, Z., MiQuel, J., MArigo, A. M., Gibson, D. I. (2012): Ultrastructure of vitellogenesis and vitellocytes in the trypanorhynch cestode Aporhynchus menezesi,a parasite of the velvet belly lanternshark Etmopterus spinax. $C$. R. Biologies 335: 573 - 584. DOI: 10.1016/j.crvi.20 12.07.007

Świderski, Z., Miquel, J., MŁocicki, D., Neifar, L., GRYTNER-ZIĘCINA, B., MACKIEWICZ, J. S. (2006a): Ultrastructural and cytochemical studies on vitellogenesis in trypanorhynch cestode Dollfusiella spinulifera Beveridge, Neifar et Euzet, 2004 (Eutetrarhynchidae). Acta Parasitol., 51: 182 - 193. DOI: 10.2478/s11686-006-0029-1
Świderski, Z., MiQuel, J., MŁOCICKI, D., NeIFAR L., GRYTNER-ZIĘCINA, B., MACKIEWICZ, J. S. (2006b): Ultrastructure of the vitellocytes in the cestode Progrillotia pastinacae Dollfus, 1946 (Trypanorhyncha, Progrillotiidae). Acta Parasitol., 51: 194 - 199. DOI: 10.2478/s11686-006-0030-8

Świderski, Z., MiQuel, J., NeIfAR, L., Mackiewicz, J. S. (2007): Ultrastructural and cytochemical studies on vitellogenesis in the trypanorhynch cestode Parachristianella trygonis Dollfus, 1946 (Eutetrarhynchidae). Acta Parasitol., 52: 114 - 126. DOI: 10.2478/s11686-007-0020-5

Świderski, Z., MŁocicki, D., MACKIEWICZ, J. S., MiQuel, J., IBRAHEEM, M. H., BRUŇANSKÁ, M. (2009): Ultrastructure and cytochemistry of vitellogenesis in Wenyonia virilis Woodland, 1923 (Cestoda, Caryophyllidea). Acta Parasitol., 54: 131 - 142. DOI: 10.2478/s11686-009-0028-0

ŚWIDERSKI, Z., MOKHTAR, F. (1974): Étude de la vitellogénèse de Bothriocephalus clavibothrium Ariola, 1899 (Cestoda: Pseudophyllidea). Z. Parasitenkd., 43: 135 149. DOI: $10.1007 / \mathrm{BF} 00328851$

ŚWIDERSKI, Z., XYLANDER, W. E. R. (2000): Vitellocytes and vitellogenesis in cestodes in relation to embryonic development, egg production and life cycle. Int. J. Parasitol., 30: 805 - 817. DOI: 10.1016/S0020-7519(00)00066-7

THIÉRY, J.-P. (1967): Mise en évidence des polysaccharides sur coupes fines en microscopie électronique. $J$. Microsc., 6: $987-1018$

XYLANDER, W. E. R. (1987): Ultrastructural studies on the reproductive system of Gyrocotylidea and Amphilinidea (Cestoda). II. Vitellaria, vitellocyte development and vitelloduct of Gyrocotyle urna. Zoomorphology, 107: 293 297

XYLANDER, W. E. R. (1988): Ultrastructural studies on the reproductive system of Gyrocotylidea and Amphilinidea (Cestoda). I. Vitellarium, vitellocyte development and vitelloduct in Amphilina foliacea (Rudolphi, 1819). Parasitol. Res., 74: 363 - 370. DOI: 10.1007/BF00539459 